\title{
ALTERATIONS IN METABOLIC ENERGETICS AND CATION TRANSPORT DURING AGING OF RED CELLS
}

\author{
By RALPH E. BERNSTEIN \\ (From the Electrolyte and Metabolic Research Unit, South African Institute for Medical Re- \\ search, Johannesburg, South Africa)
}

(Submitted for publication February 4, 1959; accepted May 14, 1959)

With the total life span of the human red cell averaging 120 days, about 0.8 per cent of the circulating erythrocytes disintegrate daily. Normal red cell destruction has been attributed to extra- and intracorpuscular factors $(1,2)$; until recently, little attention has been paid to the intrinsic processes of impaired function in normal red cells that may lead to possible disintegration. The metabolic energy of the red cell is predominantly derived from glycolytic mechanisms and is utilized to maintain transport and membrane functions and to prevent the auto-oxidation of hemoglobin (3). This investigation was designed to ascertain whether alterations in glycolysis and the activity of certain crucial enzymes concerned in the Embden-Meyerhof path occur with the in vivo aging of circulating red cells.

Centrifugation of blood aggregates young red cells (including reticulocytes) in the top layers of the packed red cell column $(4,5)$. Examination of layers of centrifuged red cells after $\mathrm{Fe}^{59}$ administration reveals that, five to 15 days later, high radioactivity is incorporated in the top fraction, while at subsequent stages in the life span, the greatest radioactivity is present in the bottom layer $(6,7)$. Fractionation of red cell samples on the basis of increasing density of the erythrocyte population with age has revealed decreases in content of water, solids and cations (4, $8)$, lipids (7) and enzyme activity (5) with age. Some chemical and enzyme activities of normal cells are lower than erythrocyte values from subjects during a reticulocyte response (9-12).

Examination of the rate of glucose disappearance, the activity of phosphohexose isomerase, aldolase and lactic apodehydrogenase and the concentration of phosphorylated intermediates of the Embden-Meyerhof path for red cell populations fractionated by differential centrifugation indicates a decrease in glycolytic and enzyme activity for old cell fractions. Energy-dependent cation transport systems also show some diminution.

\section{MATERIALS AND METHODS}

Heparinized blood from humans (normal and in response to hemorrhage) was collected in plastic or siliconed glass for centrifugation in blood cell separation tubes at $500 \mathrm{G}$ for 15 minutes; the plasma was removed for respinning to obtain a cell-free preparation and the buffy coat completely removed from the constricted part of the tube. The red cells from the bottom bulb of the tube were suspended in isotonic saline (either buffered or containing dextran or 20 per cent bovine albumin) to make a 40 per cent suspension, and a portion, constituting the original red cells, retained for analysis. After standing for 10 minutes, the remainder of the suspension was spun at $100 \mathrm{G}$ for 10 minutes, followed by $2,000 \mathrm{G}$ for $45 \mathrm{~min}$ utes. Where necessary, the estimations detailed have been corrected for the intercellular fluid trapped between the packed cells at different levels in the centrifuged cell column by the Evans blue method (13) in a separate sample spun under identical conditions.

Aliquots of the original cells and the top, middle and bottom 10 per cent fractions of centrifuged cells were measured in calibrated and siliconed pipettes for:

a. Hematologic and chemical investigations. Red cell count (two to four hemocytometer chambers counted), reticulocyte count (per 2,000 red cells) and white cell count (14); hemoglobin-alkaline hemoglobin or cyanmethemoglobin method (15); specific gravity and dry weight of cells ; and sodium, potassium, calcium and magnesium estimations by flame photometry $(16,17)$.

b. Glycolysis and phosphorus compounds. The packed red cells were resuspended in plasma or isotonic buffered phosphate saline with added glucose to give a 40 per cent suspension. The fractions were incubated simultaneously at $37^{\circ} \mathrm{C}$. in $25 \mathrm{ml}$. stoppered flasks in an air phase (a 5 per cent $\mathrm{CO}_{2}, 95$ per cent $\mathrm{O}_{2}$ gas phase was used in some experiments) and shaken at 150 cycles per minute through a small amplitude. No hemolysis was found under these conditions. The "true" glucose content of the whole suspension was estimated at zero, one and four hours after incubation at $37^{\circ} \mathrm{C}$, and the amount of glucose disappearing and lactic acid formed calculated from the one to four hour period. Glucose was estimated by the method of Somogyi and Nelson (15) or using glucose 
oxidase $^{1}$ (18) and lactic acid by the method of Barker and Summerson (19); in some cases, pyruvic acid was estimated by the method of Friedemann and Haugen (20) using toluene for specific extraction of pyruvic acid.

Phosphate compounds were estimated on trichloracetic acid filtrates of packed red cell layer fractions for inorganic phosphorus and phosphorus components by differential hydrolysis: seven minutes at $100^{\circ} \mathrm{C}$. with $\mathrm{N}$ $\mathrm{H}_{2} \mathrm{SO}_{4}$ ("easily" hydrolyzable phosphorus); 100 minutes at $100^{\circ} \mathrm{C}$. with $\mathrm{N} \mathrm{H}_{2} \mathrm{SO}_{4}$ ("difficultly" hydrolyzable phosphorus); and digestion by 60 per cent perchloric acid with heating for 2 hours, followed by addition of concentrated $\mathrm{HNO}_{3}$ and further heating for 30 minutes (total acid soluble phosphorus). Phosphate was estimated by ascorbic acid reduction of phosphomolybdate. The "easily" hydrolyzable phosphorus corresponds mainly to the two labile phosphorus groups of adenosine triphosphate (ATP); the difference between 100 minute and seven minute phosphorus to hexose, ribose and adenylate phosphorus; and the total acid soluble phosphorus less 100 minute phosphorus to $2: 3$ diphosphoglycerate $(2: 3$ DPG) predominantly and minor residual phosphate esters. Although differential hydrolysis has not the reliability of chromatographic analysis $(21,22)$, nevertheless, a preliminary comparison of paper chromatographic and differential hydrolysis methods shows close correspondence for the 2:3 DPG values. While a small amount of hydrolysis of 2:3 DPG in the seven minute or 100 minute estimations would introduce serious error, as commented on (22), we could confirm that this ester was highly resistant to acid hydrolysis (23).

c. Enzyme assays (Figure 1). Red cell phosphohexose isomerase was measured from the degree of conversion of $0.002 \mathrm{M}$ glucose-6-phosphate to fructose-6-phosphate in 30 minutes at $\mathrm{pH} 7.4$ and $37^{\circ} \mathrm{C}$., following the method of Bodansky (24) and expressed as units per gram hemoglobin. The effect of red cell phosphoglucomutase, phosphofructokinase and phosphatase on the substrate or endproduct is negligible. Aldolase was determined from the rate of conversion of fructose 1,6-diphosphate to glyceraldehyde-3-phosphate and dihydroxyacetone phosphate by the dinitrophenylhydrazine method of Sibley and Lehninger (25). The unit of aldolase activity was expressed in terms of the formation of $1 \mathrm{mg}$. alkali-labile phosphorus per $\mathrm{Gm}$. hemoglobin per minute, or using glyceraldehyde as a secondary triose standard for correction and calibration, in terms of triose phosphate chromogen (26).

Red cell lactic apodehydrogenase was determined from the formation of diphosphopyridine nucleotide from reduced diphosphopyridine nucleotide (DPNH) during the conversion of pyruvate to lactate. The method of Blanchaer and Baldwin (27) was used and the unit of activity expressed as a decrease in optical density ( $\Delta$ O.D.) of 1.00 at $340 \mathrm{~m} \mu$ per $\mathrm{Gm}$. hemoglobin per minute.

${ }^{1}$ High potency enzyme preparations kindly supplied by Ames Co., London, and Dr. L. A. Underkofler, Takamine Laboratories, Clifton, New Jersey.
TABLE I

Physicochemical data for centrifuged red cell layers

\begin{tabular}{|c|c|c|c|}
\hline & \multicolumn{3}{|c|}{ Fraction of red cell column } \\
\hline & $\begin{array}{l}\text { Top } \\
10 \%\end{array}$ & $\begin{array}{l}\text { Middle } \\
10 \%\end{array}$ & $\begin{array}{l}\text { Bottom } \\
10 \%\end{array}$ \\
\hline Reticulocyte count* (\%) & 36 & 1.2 & 0 \\
\hline Red cell count $\left(10^{\circ} / \mathrm{ml}\right.$. cells) & 9.8 & 11.9 & 12.8 \\
\hline Hemoglobin $(\mathrm{Gm} . / \mathrm{ml}$. cells $)$ & 0.272 & 0.320 & 0.338 \\
\hline Density $(\mathrm{Gm} . / \mathrm{ml}$. cells) & 1.102 & 1.110 & 1.115 \\
\hline Dry weight $(\mathrm{Gm} . / \mathrm{ml} . \mathrm{cells})$ & 0.363 & 0.402 & 0.420 \\
\hline Water content $(\%)$ & 67.1 & 63.8 & 62.3 \\
\hline Cell weight $(\mu \mu g)$. & 112 & 93 & 87 \\
\hline Cell water $(\mu \mu g)$. & 75 & 59 & 54 \\
\hline Cell solids $(\mu \mu \mathrm{g})$. & 37 & 34 & 33 \\
\hline Cell hemoglobin $\left(\mu \mu g_{.}\right)$ & 27.8 & 26.8 & 26.4 \\
\hline Cell volume $(c u, \mu)$ & 101 & 84 & 78 \\
\hline $\begin{array}{l}\text { Cell volume }(c u . \mu) \\
\quad \text { (from hematocrit) }\end{array}$ & 108 & 88 & 79 \\
\hline
\end{tabular}

* Values based on average of 12 samples with whole population reticulocyte counts of 5 to 10 per cent.

d. Presentation and precision of analyses. Calculation of results in terms of volume (or weight) of red cells, volume (or weight) of cell water or of cell solids does not provide a valid comparison for analyses taken from different layers, especially in the presence of a moderate to marked reticulocytosis. Alterations in the size, water content and solid content of a red cell during its life span are appreciable $(4,28)$ and the data presented in Table I indicate that results, where possible, should be referred to the hemoglobin content of the particular sample assayed. While synthesized to a slight degree by reticulocytes and undergoing some degradation at the end of the erythrocyte's life span, the hemoglobin content of the red cell remains virtually unchanged. Results expressed per unit number of red cells are subject to the relatively large error for red cell counts.

All readings were made on an Evelyn filter photometer (using the micro attachment when necessary) or the Beckman DC spectrophotometer. The precision of enzyme assays was checked by duplicate estimations; the percentage error ranged from 3 to 10 per cent. Duplicate estimations on red cell samples fractioned for the phosphate partition are presented in Table II. Since values obtained from the differential hydrolysis are interdependent, the analysis was repeated when errors greater than 10 per cent occurred. Errors of 3 to 8 per cent were found for the different phosphate components. For the other chemical determinations, the reproducibility of replicate estimations and the accuracy, assessed by recovery of the substance being determined from additions to red cell suspensions, had errors of less than 2 per cent.

\section{RESULTS}

On centrifugation, some 65 to 75 per cent of the total reticulocytes of the original population became concentrated in the top zero to two-tenths fraction of the packed cell column, and 45 to 55 


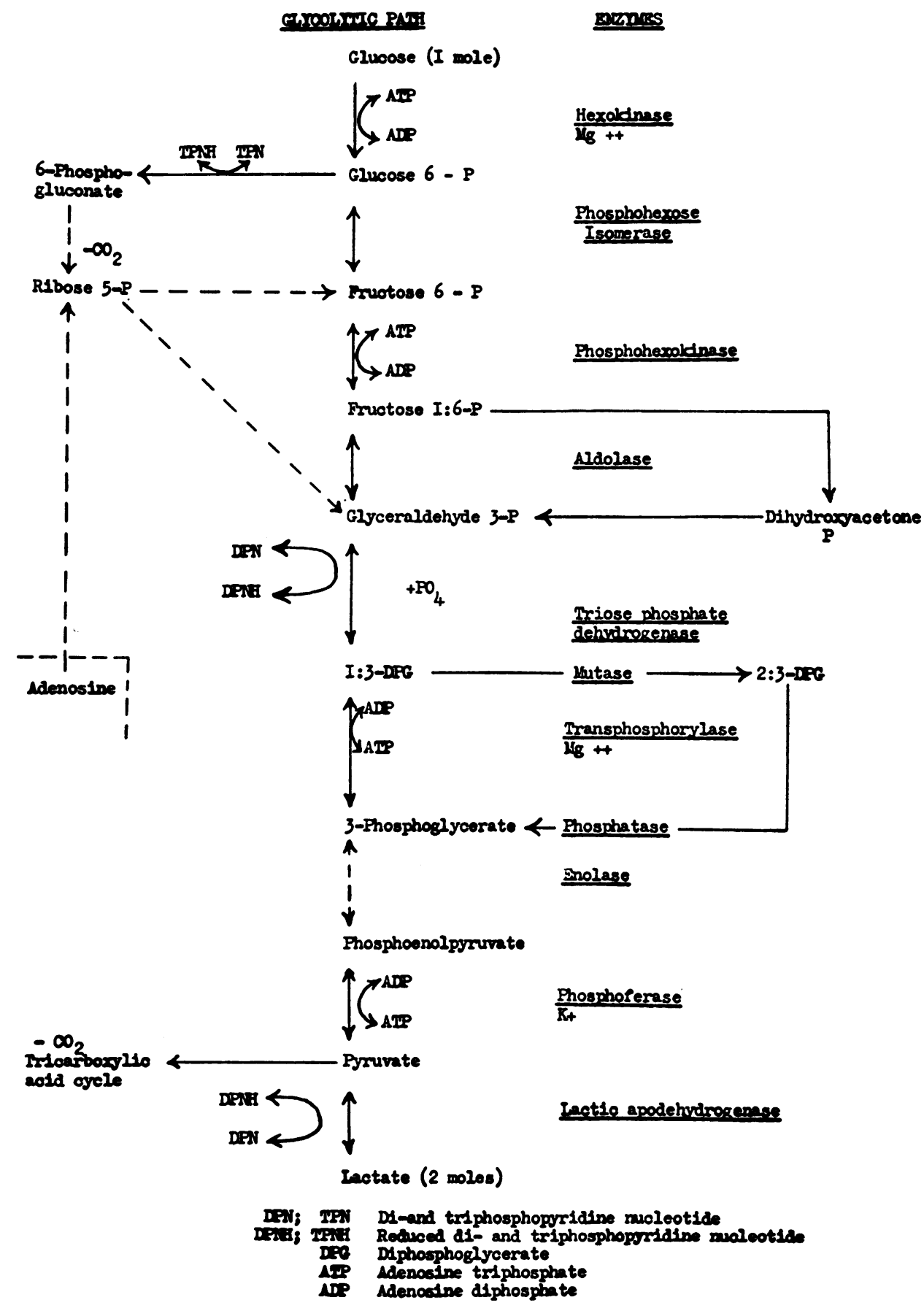

Fig. 1. Degradation of Glucose to Lactate in the Red Cell

Broken arrows indicate omission of intermediate steps.

per cent in the top zero to one-tenth fraction. For normal subjects with reticulocyte counts of 0.4 to 1.4 per cent, the top zero to one-tenth fraction contained 2 to 8 per cent reticulocytes. Subjects with a reticulocytosis were mainly cases several days after a hemorrhage, when the level of circulating reticulocytes reached 2 to 10 per cent. Blood samples with a 5 per cent reticulocyte count concentrated a 25 per cent reticulocyte count in the top zone on centrifugation, while specimens 
TABLE II

Precision of differential phosphate partition in 50 duplicate red cell samples

\begin{tabular}{|c|c|c|c|c|c|c|c|}
\hline \multirow[b]{2}{*}{ Phosphate component* } & \multicolumn{2}{|c|}{ Sample 6} & \multicolumn{2}{|c|}{ Sample 11} & \multicolumn{2}{|c|}{ Sample 18} & \multirow{2}{*}{$\begin{array}{c}\text { Standard } \\
\text { deviation } \\
\text { of difference } \\
\text { between } \\
\text { duplicatest }\end{array}$} \\
\hline & $x_{1}$ & $x_{2}$ & $x_{1}$ & $x_{2}$ & $x_{1}$ & $x_{2}$ & \\
\hline & \multicolumn{6}{|c|}{$\mu M o l e s P / G m$. hemoglobin } & \\
\hline $\begin{array}{l}\text { Inorg. } P \\
\text { EHP ( } 7 \text { min.) } \\
\text { DHP (100 min. }-7 \text { min.) } \\
2: 3 \text { DPG }\end{array}$ & $\begin{array}{r}5.15 \\
7.15 \\
6.06 \\
28.50\end{array}$ & $\begin{array}{r}4.75 \\
7.50 \\
5.54 \\
29.80\end{array}$ & $\begin{array}{r}4.67 \\
6.95 \\
4.12 \\
23.24\end{array}$ & $\begin{array}{r}4.90 \\
7.25 \\
3.87 \\
24.76\end{array}$ & $\begin{array}{r}8.70 \\
9.28 \\
5.97 \\
22.44\end{array}$ & $\begin{array}{r}8.86 \\
8.32 \\
5.72 \\
21.56\end{array}$ & $\begin{array}{l} \pm 0.18 \\
\pm 0.48 \\
\pm 0.30 \\
\pm 1.35\end{array}$ \\
\hline
\end{tabular}

* Inorg. $\mathrm{P}=$ inorganic phosphate; EHP = easily hydrolyzable phosphate (mainly adenosine triphosphate); DHP = difficultly hydrolyzable phosphate (hexose and adenylic phosphate); and 2:3 DPG $=2: 3$ diphosphoglycerate.

†. D. $=\left[\Sigma\left(x_{1}-x_{2}\right)^{2} / n-1\right]^{3}$.

with an original reticulocyte percentage of 10 showed over 50 per cent reticulocytes in the top layer.

The number of reticulocytes decreased sharply in successive fractions and few reticulocytes were found in the five-tenths to one level (Table III).

The possible effect of the presence of white cells and platelets on glycolysis and biochemical values of the various red cell fractions was found to be slight. Bottom layers revealed a virtual absence of platelets and 0 to $6 \times 10^{5}$ leukocytes per ml. cells, i.e., white : red cell ratio of $<1: 20,000$; and an occasional platelet and some 8 to $18 \times 10^{5}$ leukocytes per $\mathrm{ml}$. cells for top fractions, viz. a white: red cell proportion of about $1: 10,000$. For white: red cell ratios of $1: 500$ to 1,000 in normal whole blood, some 15 to 25 per cent of whole blood glycolysis has been attributed to the leukocytes $(29,30)$. Contamination of the top fraction of red cells with leukocytes could thus produce a 3 per cent maximum enhancement of red cell glycolysis; errors of a lesser order were calculated for erythrocyte phosphate compounds and cation contents.

\section{Glycolysis}

Rates of glucose utilization. The various steps in the red cell glycolytic cycle are depicted in Figure 1. Overall glycolysis was assessed by the amount of glucose degraded and lactate formed. In an initial series of experiments, analyses of packed red cells at fractional intervals showed a

TABLE III

Glucose utilization and lactic acid formation in original and fractionated normal red cells during three hours' incubation at $37^{\circ} \mathrm{C}$. in air

\begin{tabular}{|c|c|c|c|c|c|c|c|}
\hline & \multirow{2}{*}{$\begin{array}{c}\text { Original } \\
\text { cells }\end{array}$} & \multicolumn{6}{|c|}{ Fraction of red cell column } \\
\hline . & & $0-0.1$ & $0.1-0.2$ & $0.2-0.4$ & $0.4-0.6$ & $0.6-0.8$ & $0.8-1.0$ \\
\hline \multicolumn{8}{|l|}{ Normals [24] } \\
\hline Reticulocytes (\%) & 0.9 & 6 & 2.3 & 0.4 & 0 & 0 & 0 \\
\hline $\begin{array}{l}\text { Glucose utilized } \\
(\mu M \text { Moles } / G m . \text { hemoglobin } / h r .)\end{array}$ & 6.3 & 11.4 & 8.8 & 7.1 & 6.3 & 5.2 & 4.3 \\
\hline $\begin{array}{l}\text { Lactic acid formed } \\
(\mu \text { Moles } / G m . \text { hemoglobin } / h r .)\end{array}$ & 12.1 & 19.7 & 16.7 & 13.9 & 11.9 & & 8.3 \\
\hline Conversion (\%) & 96 & 86 & 95 & 98 & 94 & & 96 \\
\hline \multicolumn{8}{|l|}{ Reticulocytosis [8] } \\
\hline Reticulocytes (\%) & 6 & 28 & 17 & 13 & 0.5 & 0 & 0 \\
\hline $\begin{array}{l}\text { Glucose utilized } \\
(\mu M \text { oles } / G m . \text { hemoglobin } / h r .)\end{array}$ & 7.2 & 20,0 & 13.2 & 9.3 & 6.6 & 5.3 & 4.6 \\
\hline $\begin{array}{l}\text { Lactic acid formed } \\
\qquad(\mu \text { Moles } / \mathrm{Gm} . \text { hemoglobin } / \mathrm{hr} .)\end{array}$ & 13.8 & 32.7 & 23.8 & 17.2 & 13.0 & & 8.4 \\
\hline Conversion $(\%)$ & 96 & 82 & 90 & 92 & 98 & & 91 \\
\hline
\end{tabular}


TABLE IV

The effect of in vitro incubation at $37^{\circ} \mathrm{C}$. in air for 24 hours on the rate of red cell glycolysis

\begin{tabular}{|c|c|c|c|c|}
\hline & \multirow{2}{*}{$\begin{array}{c}\text { Original } \\
\text { cells }\end{array}$} & \multicolumn{3}{|c|}{ Fraction of red cell column } \\
\hline & & Top $10 \%$ & Middle $10 \%$ & Bottom 10\% \\
\hline \multicolumn{5}{|l|}{ Beginning of period } \\
\hline Reticulocytes (\%) & 2.4 & 10 & 0.3 & 0 \\
\hline $\begin{array}{l}\text { Glucose utilized } \\
(\mu \text { Moles } / \text { Gm. hemoglobin } / h r .)\end{array}$ & 5.9 & 12.8 & 6.0 & 5.1 \\
\hline $\begin{array}{l}\text { Lactic acid formed } \\
\quad(\mu \text { Moles } / \text { Gm. hemoglobin } / \text { hr. })\end{array}$ & 11.2 & 22.4 & 11.2 & 9.4 \\
\hline \multicolumn{5}{|l|}{ End of period } \\
\hline Reticulocytes (\%) & 0.4 & 1.6 & 0 & 0 \\
\hline $\begin{array}{l}\text { Glucose utilized } \\
(\mu \text { Moles } / \text { Gm. hemoglobin } / h r .)\end{array}$ & 5.2 & 9.2 & 5.6 & 4.5 \\
\hline $\begin{array}{l}\text { Lactic acid formed } \\
(\mu \text { Moles } / \text { Gm. hemoglobin } / h r .)\end{array}$ & 9.7 & 16.5 & 10.7 & 9.1 \\
\hline
\end{tabular}

progressive decrease in glycolytic rate from the top to the bottom layer zone (Table III). For the cases with reticulocytosis, the increased rate of glycolysis in the top fractions was accentuated. The glycolytic rate of the reticulocyte would appear to be approximately eight times that of old cell populations from the bottom centrifuged fraction and five times that of the average whole cell population.

The greater rate of glycolysis in red cells from the top layers was not solely due to the aggregation of reticulocytes in these fractions, since the glycolytic rate was higher in the four to sixtenths and six to eight-tenths fractions compared with the eight-tenths to one fraction layers where the reticulocyte was extremely scanty. The aging of red cells with progressive decrement in glycolytic activity was further indicated by the following experiment. Red cells from the original suspension and the top, middle and bottom 10 per cent fractional parts of blood samples with a reticulocytosis were incubated for 24 hours at $37^{\circ} \mathrm{C}$. with estimation of the glycolytic rate at the beginning and end of the incubation period. Probably due to in vitro deterioration, there was a relative decrease in glycolytic rates of all fractions at the termination of incubation (Table IV). However, the high glycolytic rate of the top fraction after 24 hours' incubation was noteworthy, since the reticulocytes had virtually disappeared from all fractions owing to maturation. Seip (31) concludes that two-thirds to three-fourths of circu- lating reticulocytes lose their reticulum in 30 hours. The supposition is that the decrease in glycolytic activity progressed with aging of the red cells.

The production of lactate was approximately equivalent to the amount of glucose degraded in bottom fraction cells. The lower percentage conversion of glucose to lactate in the top fraction of the cell column suggested divergence of glycolytic intermediates into other metabolic paths in young cells (see Discussion). The final $\mathrm{pH}$ of the suspension was 0.1 to $0.3 \mathrm{pH}$ units lower at the end of incubation, depending on the degree of glycolytic activity, and was higher for the air than the 5 per cent $\mathrm{CO}_{2}, 95$ per cent $\mathrm{O}_{2}$ gas phase. Longer periods of incubation, despite the provision of additional buffer in the suspension systems, produced decreases of 0.5 to $0.8 \mathrm{pH}$ units with some inhibition of glycolysis.

In a further series of experiments, top and bottom fraction cells were incubated in various media (Table V). Suspension of cell fractions, in solutions containing fructose, mannose or galactose instead of glucose and incubated at $37^{\circ} \mathrm{C}$., resulted in entry of these sugars into red cells as judged by their decreasing concentration in the external medium and their metabolism as evidenced by acid production. Sugar degradation was greater in the top fraction independent of the suspending medium and greater lactic acid formation occurred in the suspension from the top portion. Fructolysis and formation of acid was marked 
TABLE V

Rates of sugar degradation for top and bottom red cell fractions from normal blood sample suspended in various media

\begin{tabular}{|c|c|c|c|c|}
\hline \multirow[b]{2}{*}{ Suspending medium } & \multicolumn{2}{|c|}{ Top fraction } & \multicolumn{2}{|c|}{ Bottom fraction } \\
\hline & $\begin{array}{c}\text { Sugar } \\
\text { utilized }\end{array}$ & $\begin{array}{l}\text { Lactic acid } \\
\text { formed }\end{array}$ & $\begin{array}{c}\text { Sugar } \\
\text { utilized }\end{array}$ & $\begin{array}{l}\text { Lactic acid } \\
\text { formed }\end{array}$ \\
\hline & \multicolumn{2}{|c|}{$\mu$ Moles $/$ Gm. hemoglobin $/ \mathrm{hr}$. } & \multicolumn{2}{|c|}{ pMoles $/ \mathrm{Gm}$. hemoglobin $/ \mathrm{hr}$} \\
\hline Glucose-phosphate-saline* & 11.6 & 20.1 & 5.2 & 10.0 \\
\hline Fructose-phosphate-saline & 12.1 & 20.2 & 4.8 & 9.1 \\
\hline Mannose-phosphate-salinet & 8.0 & 14.8 & 3.6 & 6.3 \\
\hline Galactose-phosphate-saline $f$ & 2.2 & $5.4 \S$ & 0.9 & $3.0 \S$ \\
\hline Adenosine-phosphate-saline $\|$ & & $18.6^{\circ}$ & & 8.5 \\
\hline Plasma, heparinized & 10.9 & 19.2 & 4.8 & $\begin{array}{l}0.3 \\
8.9\end{array}$ \\
\hline Plasma, oxalated & 8.6 & 16.5 & 4.0 & 7.8 \\
\hline
\end{tabular}

* Concentration of hexose sugars, $2 \mathrm{mg}$. $/ \mathrm{ml}$.

$\dagger$ Estimation by Seliwanoff resorcinol- $\mathrm{HCl}$ method (Reference 15, p. 229).

$\ddagger$ Estimation by glucose method after fermentation, using appropriate factor (15).

$\S$ Includes lactic acid formed from cell hexose phosphate.

|| Concentration of adenosine, $1 \mathrm{mg}$. $/ \mathrm{ml}$.

and similar to glucose in degree. The utilization of mannose was less and the metabolism of galactose was of slight degree. Adenosine or inosine could replace glucose either wholly or in part as a substrate for glycolysis. Purine nucleosides are metabolized by red cells, forming ribose5 -phosphate which may enter the glycolytic pathway (Figure 1). Both oxalate and ethylenediamine tetraacetate were considered unsuitable as anticoagulants since they depressed glycolytic rates considerably.

Phosphorylated compounds and glycolytic enzymes. The phosphate partition of the various centrifugated fractions is presented in Table VI for specimens of blood from 18 normal subjects

TABLE VI

Phosphate partition in red cell fractions

\begin{tabular}{|c|c|c|c|c|}
\hline \multirow{3}{*}{$\begin{array}{l}\text { Phosphate } \\
\text { compo- } \\
\text { nent* }\end{array}$} & \multicolumn{4}{|c|}{ Fraction of cell column } \\
\hline & \multicolumn{2}{|c|}{ Normals $[18] \dagger$} & \multicolumn{2}{|c|}{ Reticulocytosis [7] } \\
\hline & $\begin{array}{l}\text { Top } \\
10 \%\end{array}$ & $\begin{array}{c}\text { Bottom } \\
10 \%\end{array}$ & $\begin{array}{l}\text { Top } \\
10 \%\end{array}$ & $\begin{array}{c}\text { Bottom } \\
10 \%\end{array}$ \\
\hline & \multicolumn{4}{|c|}{$\mu$ Moles $P / G m$. hemoglobin } \\
\hline Inorg. $\mathrm{P}$ & $\begin{array}{c}4.7 \\
+0.42\end{array}$ & $\begin{array}{l}5.6 \\
\pm 0.30\end{array}$ & $\begin{array}{c}4.1 \\
(3.0-5.5)\end{array}$ & $\begin{array}{c}5.2 \\
(4.4-6.3)\end{array}$ \\
\hline EHP & $\begin{array}{c}9.1 \\
\pm 0.68\end{array}$ & $\begin{array}{c}7.0 \\
\pm 0.55\end{array}$ & $\begin{array}{c}11.8 \\
(8.1-14.6)\end{array}$ & $\begin{array}{c}7.3 \\
(6.2-8.0)\end{array}$ \\
\hline DHP & $\begin{aligned} & 4.5 \\
\pm & 0.32\end{aligned}$ & 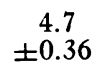 & $\begin{array}{c}5.1 \\
(4.3-6.1)\end{array}$ & $\begin{array}{c}4.1 \\
(2.9-5.0)\end{array}$ \\
\hline $2: 3 \mathrm{DPG}$ & $\begin{array}{r}29.9 \\
\pm 2.4\end{array}$ & $\begin{array}{r}25.9 \\
\pm 2.7\end{array}$ & $\begin{array}{c}33.7 \\
(29.2-38.1)\end{array}$ & $\begin{array}{c}23.8 \\
(19.2-29.5)\end{array}$ \\
\hline
\end{tabular}

* See footnote, Table II.

+ Values are means of duplicate estimations \pm S. D.

$\ddagger$ Mean and range of duplicate estimations. and seven cases with reticulocytosis. The high concentration of 2:3 DPG is peculiar to certain mammalian red cells and represented some 60 per cent of the total phosphate analyzed, with a further 15 per cent for the readily hydrolyzable phosphate, corresponding mainly to the two labile groups of ATP. The 2:3 DPG represents a stable store of phosphate ester (Figure 1) with a high rate of turnover $(22,23)$. The top fraction of centrifuged cells had a higher concentration of 2:3 DPG than lower levels in 16 of the 18 normal samples, exceeding the 95 per cent confidence limits for the reproducibility of duplicate estimations given in Table II. The difference of the means, 4.0, was significant, since it exceeded three times its standard error, \pm 0.86 . The readily hydrolyzable phosphate also tended to have higher concentrations in the top strata of the centrifuged cell column, 13 values exceeding 95 per cent confidence limits for the reproducibility of estimations. The difference of the means, 2.1, was significant by comparison with its standard error, \pm 0.21 . These deviations were accentuated in the cases of reticulocytosis examined. For other phosphate components (inorganic, difficultly hydrolyzable and total acid soluble phosphate), no clear-cut difference was evident for the various fractions.

When aliquots from different strata of packed cells were washed in isotonic glucose-free solutions and incubated without glucose, the result was a rapid decrease in 2:3 DPG content with a slower diminution in ATP, and a concomitant 
increase in the inorganic phosphate content of the cell. Table VII depicts the changes that occur in the initial three hour period of incubation for one of five experiments with similar results. Approximately 10 per cent and 20 per cent of $2: 3$ DPG were catabolized hourly in bottom and top fraction cells, respectively. Since the conversion of 2:3 DPG to pyruvate involves the formation of 1 Mole ATP (easily hydrolyzable phosphate) for each Mole 2:3 DPG dissimulated (Figure 1), the total loss of ATP from the system was represented by the combined ATP and 2:3 DPG decrease. For top fraction cells, the loss was nearly twice that for the bottom fraction, indicative of the greater inherent metabolic activity of upper layer erythrocytes. The difference between the mean decrease in five experiments of 2:3 DPG (and total ATP loss) was highly significant, exceeding six times the standard error of the difference.

The degradation of the phosphate esters and the formation of lactic acid decreased progressively with continued incubation, the hourly rate of change for six hours' incubation being about 60 per cent of that calculated for the three hour period. With longer periods of incubation, increasing rate of disappearance of easily hydrolyzable phosphate with rise in inorganic phosphate heralded the onset of hemolysis.

Apart from small amounts of hexose and pentose phosphates in the red cell, the 2:3 DPG provided the major source of energy (equivalent to 50 to 70 per cent of the lactic acid formed) in the absence of glucose or other metabolizable sugar in the external medium. Some accumulation of pyruvate occurred in cells derived from the bot-

TABLE VII

Incubation of normal red cell fractions at $37^{\circ} \mathrm{C}$. for three hours without glucose

\begin{tabular}{|c|c|c|}
\hline Phosphate and glycolytic components* & $\begin{array}{c}\text { Top } \\
\text { fraction }\end{array}$ & $\begin{array}{l}\text { Bottom } \\
\text { fraction }\end{array}$ \\
\hline 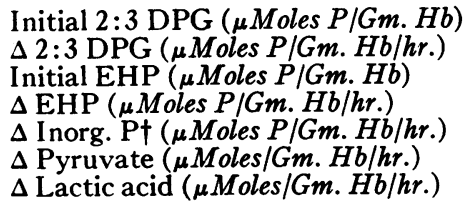 & $\begin{array}{r}30.2 \\
-4.3 \\
8.5 \\
-0.5 \\
+4.5 \\
+0.2 \\
+7.2\end{array}$ & $\begin{array}{r}22.5 \\
-2.3 \\
6.8 \\
-0.3 \\
+2.8 \\
+0.6 \\
+3.5\end{array}$ \\
\hline
\end{tabular}

* See footnote, Table II; Hb = hemoglobin.

$\dagger$ This is estimated from the observed change in cell inorganic phosphorus plus cell phosphorus lost by diffusion, evaluated by difference in total cell phosphorus before and after incubation. tom layer of the centrifuged column (Table VII). Since pyruvate accumulation was not found in the same red cell fractions in the presence of glucose, it was postulated that the decrease of conversion of glyceraldehyde 3-phosphate to $2: 3$ DPG in glucose-free media created a diminution in the formation of $\mathrm{DPNH}$ and a relative deficiency of DPNH (coenzyme) for lactic apodehydrogenase conversion of pyruvate to lactate (Figure 1). Analogous mechanisms to explain pyruvate accumulation have been suggested by Whittam (32) for fresh red cells incubated without glucose and by Blanchaer and Baldwin (27) for slowly glycolyzing cold-stored cells. Pyruvate accumulation was not as evident in the upper fraction of red cells incubated in glucose-free media, presumably since pyruvate in reticulocytes can be metabolized by other routes.

Spinning the cell aliquots and resuspension in solutions containing adenosine (or inosine) for incubation at $37^{\circ} \mathrm{C}$. led to a regeneration of the ATP (easily hydrolyzable phosphate) and 2:3 DPG; the former reached nearly original values in 30 minutes and the latter by 120 minutes, with the upper fraction cells having higher concentrations than bottom cells. Resuspension in glucoseinorganic phosphate buffer resulted in a slower and less complete resynthesis of these phosphate esters.

The enzyme activities of phosphohexose isomerase and aldolase showed a progressive decrease from young (top fraction) to old (bottom fraction) red cell populations. Values for different studies are collected in Table VIII and indicate that the top fraction of cells from normal blood had an enzyme activity some 80 per cent greater than bottom fraction cells. On this basis, the reticulocyte phosphohexose isomerase and aldolase activity was several times that of the general cell population. Fractional parts, incubated at $37^{\circ} \mathrm{C}$. for 24 hours and reanalyzed, showed some 20 per cent decrease in enzyme activity. However, while few reticulocytes could be detected in the top fraction (having undergone maturation), the enzyme activity of this portion was still greater than that for the other layers, indicating the progressive nature of the loss of activity for these enzymes with aging of the red cells.

Lactic apodehydrogenase activity, on the other 
TABLE VIII

Enzyme assays in red cell fractions

\begin{tabular}{|c|c|c|c|c|}
\hline & Reticulocytes & $\begin{array}{c}\text { Phosphohexose } \\
\text { isomerase* }\end{array}$ & Aldolaset & $\begin{array}{l}\text { Lactic apode- } \\
\text { hydrogenase* }\end{array}$ \\
\hline Normals, No. of values & 17 & $\begin{array}{c}\text { 10sunits/Gm.Hb } \\
14\end{array}$ & $\begin{array}{c}\text { units/Gm. Hb/min. } \\
8\end{array}$ & 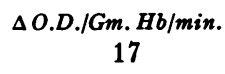 \\
\hline $\begin{array}{l}\text { Original suspension } \\
\text { Top } 10 \% \text { fraction } \\
\text { Middle } 10 \% \text { fraction } \\
\text { Bottom } 10 \% \text { fraction }\end{array}$ & $\begin{array}{l}0.8 \\
4.2 \\
0.2 \\
0\end{array}$ & $\begin{array}{l}12.8 \pm 1.5 \\
19.4 \pm 2.6 \\
14.5 \pm 2.2 \\
11.6 \pm 1.8\end{array}$ & $\begin{array}{l}0.29 \\
0.48 \\
0.30 \\
0.23\end{array}$ & $\begin{array}{l}158 \pm 22 \\
180 \pm 31 \\
150 \pm 26 \\
169 \pm 18\end{array}$ \\
\hline \multicolumn{5}{|l|}{ Subject M. A. } \\
\hline $\begin{array}{l}\text { Original suspension } \\
\text { Top } 10 \% \text { fraction } \\
\text { Bottom } 10 \% \text { fraction }\end{array}$ & $\begin{array}{c}3.5 \\
15.5 \\
0\end{array}$ & $\begin{array}{r}10.6 \\
25.5 \\
8.2\end{array}$ & $\begin{array}{l}0.18 \\
0.38 \\
0.14\end{array}$ & $\begin{array}{l}192 \\
198 \\
174\end{array}$ \\
\hline \multicolumn{5}{|l|}{ Subject W. F. } \\
\hline $\begin{array}{l}\text { Original suspension } \\
\text { Top } 10 \% \text { fraction } \\
\text { Bottom } 10 \% \text { fraction } \\
\text { Original suspension } \ddagger \\
\text { Top } 10 \% \text { fraction } \ddagger \\
\text { Bottom } 10 \% \text { fraction } \ddagger\end{array}$ & $\begin{array}{c}9.5 \\
42.0 \\
0 \\
1.8 \\
7.2 \\
0\end{array}$ & $\begin{array}{l}14.6 \\
35.3 \\
11.9 \\
12.9 \\
20.5 \\
10.7\end{array}$ & $\begin{array}{l}0.24 \\
0.53 \\
0.17 \\
0.32\end{array}$ & $\begin{array}{l}143 \\
135 \\
152 \\
165 \\
150 \\
176\end{array}$ \\
\hline
\end{tabular}

$*$ Mean \pm S. D.

+ Mean.

$\ddagger$ Estimations 18 days later.

hand, showed little difference between the various fractional parts from the same blood sample.

In five cases of reticulocytosis examined during the episode and subsequently, the glycolytic rates and enzyme activity (phosphohexose isomerase and aldolase) of the isolated top fraction of cells had decreased considerably from the values during the reticulocytosis, as had the degree of reticulocytosis (Table VIII).

\section{Cation transport}

The red cell potassium and sodium values for the different cell fractions are presented in Table
IX. The top fraction (reticulocytes and young mature erythrocytes) had a higher potassium and lower sodium than cells from the bottom fraction. The concentrations so obtained represented the cation steady state of the fraction of red cells analyzed, so that the transport of cations into and out of red cells was decreased in the more mature cells. The potassium and sodium contents, considered however in terms of concentrations in cell water, indicated that there was no change in osmotic relations.

The calcium content of red cells was small and no variation in values could be detected among

TABLE IX

Cation contents of top and bottom fractions from normal centrifuged cells

\begin{tabular}{|c|c|c|}
\hline & \multicolumn{2}{|c|}{ Mean values in red cells } \\
\hline & Top fraction & Bottom fraction \\
\hline $\begin{array}{l}\text { Potassium (mMoles } / L . \text { red cells) } \\
\text { Sodium (mMoles } / L . \text { red cells) } \\
\text { Potassium (mMoles } / L . \text { cell water) } \\
\text { Sodium (mMoles } / L \text {. cell water) } \\
\text { (K + Na) (mMoles } / L . \text { cell water) } \\
\text { Potassium ( } \mu \text { Moles } / G m \text {. hemoglobin) } \\
\text { Sodium ( } \mu \text { Moles } / G m \text {. hemoglobin) } \\
\text { Calcium ( } \mu \text { Moles } / G m \text {. hemoglobin) } \\
\text { Magnesium ( } \mu \text { Moles } / G m \text {. hemoglobin) }\end{array}$ & $\begin{array}{r}112 \\
11 \\
161 \\
16 \\
177 \\
415 \pm 22(28)^{*} \\
39 \pm 5(28) \\
3.6 \pm 0.5(18) \\
12.4 \pm 2.2(11)\end{array}$ & $\begin{array}{l}97 \\
20 \\
149 \\
31 \\
180 \\
294 \pm 15(28) \\
64 \pm 8(25) \\
3.2 \pm 0.8(18) \\
7.8 \pm 1.6(9)\end{array}$ \\
\hline
\end{tabular}

* Standard deviation with number of estimations in parentheses. 
TABLE $X$

Effect of refrigeration on phosphate components and cation contents of red cell fractions in ACD medium

\begin{tabular}{|c|c|c|c|c|c|c|c|c|c|c|c|c|}
\hline \multirow{3}{*}{$\begin{array}{c}\text { Day of } \\
\text { refrigera- } \\
\text { tion }\end{array}$} & \multirow{2}{*}{\multicolumn{2}{|c|}{ Glycolysis }} & \multicolumn{6}{|c|}{ Phosphate components* } & \multicolumn{4}{|c|}{ Cation } \\
\hline & & & \multicolumn{2}{|c|}{ EHP } & \multicolumn{2}{|c|}{ 2:3 DPG } & \multicolumn{2}{|c|}{ Inorg. Pł } & \multicolumn{2}{|c|}{$\mathbf{K}$} & \multicolumn{2}{|c|}{$\mathrm{Na}$} \\
\hline & $\overline{\mathrm{T} \dagger}$ & $\bar{B}$ & $T$ & B & $\mathbf{T}$ & B & $\mathbf{T}$ & B & $T$ & B & $T$ & B \\
\hline & \multicolumn{2}{|c|}{ $\mu$ Moles $/ \mathrm{Gm} . \mathrm{Hb} / \mathrm{hr}$. } & \multicolumn{6}{|c|}{$\mu$ Moles $P / G m$. hemoglobin } & \multicolumn{4}{|c|}{$\mu E q . / G m$. hemoglobin } \\
\hline 1 & 0.8 & 0.2 & 7.3 & 6.3 & 28.6 & 24.7 & 5.0 & 4.2 & 4008 & 320 & 33 & 52 \\
\hline 3 & & & 6.7 & 5.0 & 25.8 & 21.4 & 7.8 & 6.7 & $318^{\circ}$ & 246 & 102 & 108 \\
\hline 5 & 0.6 & 0.3 & 6.2 & & 24.0 & 18.9 & 9.6 & 9.5 & 264 & 188 & 156 & 187 \\
\hline 10 & 0.4 & 0.2 & 6.0 & 4.4 & 21.8 & 15.3 & 11.3 & 13.4 & 186 & 93 & 232 & 271 \\
\hline
\end{tabular}

* See footnote, Table II.

$\dagger \mathrm{T}=$ top $10 \%$ fraction; $\mathrm{B}=$ bottom $10 \%$ fraction; $\mathrm{Hb}=$ hemoglobin.

¥ This is estimated from the observed change in cell inorganic phosphorus plus cell phosphorus lost by diffusion, evaluated by difference in total cell phosphorus before and after incubation.

\& Initial concentrations were: $\mathrm{K}, 116$ and $104 ; \mathrm{Na}, 9.5$ and $17 \mathrm{mEq}$./L., top and bottom cells.

$\|$ Final concentrations were: $\mathrm{K}, 54$ and $30 ; \mathrm{Na}, 67$ and $88 \mathrm{mEq}$./L., top and bottom cells.

the different fractions. In the case of red cell magnesium, the series analyzed to date is small, but the results suggested some decrease of this element in the old cell populations.

Fractions from the different layers were suspended in preservative media [acid citrate dextrose $(\mathrm{ACD})$; ACD with adenosine or inosine; and the "synthetic" plasma medium of Raker, Taylor, Weller and Hastings (33)] and refrigerated at $5^{\circ} \mathrm{C}$. for various times. Potassium and sodium diffused across the red cell membrane according to their electrochemical gradients so that sodium accumulated and potassium decreased intracellularly (Table X). Despite the larger cation concentration gradient of top fraction cells, the bottom cell layer lost more potassium and gained more sodium. This could be attributed to active cation transport being slightly greater in the top fraction cells. While red cell glycolysis at $5^{\circ} \mathrm{C}$. proceeded at a low rate, viz., 0.2 to 1.0 $\mu$ Mole glucose dissimulated per $\mathrm{Gm}$. hemoglobin per hour, less than 10 per cent of the rate at $37^{\circ} \mathrm{C}$., the greater glycolysis of top fraction cells and the lesser disappearance of easily hydrolyzable phosphate (ATP) and 2:3 DPG during refrigeration linked the energy of glycolysis to active cation transport. Iodoacetate and fluoride abolished these differential effects in refrigerated top and bottom cell fractions on glycolysis, phosphorus esters and cation concentrations, while cardiac glycosides (which affect carrier-transport systems) eliminated the differential cation effects only (to be published).

Samples removed daily from, the refrigerated specimens provided a series of top and bottom cell fractions with progressive alteration of potassium and sodium content from their original values depending on the time of refrigeration. The gross accumulation of potassium and extrusion of sodium after incubation of a representative refrigerated sample for 6 hours at $37^{\circ} \mathrm{C}$. is given in Table XI. Since the initial cation concentrations of top and bottom fractions before storage were not too widely divergent, the dependence of active and passive transport on the cellular and external concentration of these ions can be assumed to be similar. Passive transport at $37^{\circ} \mathrm{C}$. has been assessed in the same cell fractions by two methods: 1) incubation of an aliquot with cardiac glycosides to inhibit transport systems (34); and 2) suspension of high potassium (sodium deficient) and high sodium (potassium deficient) cells in isotonic choline chloride under the same conditions. Results of a similar order were obtained. The gross gain or loss of a particular cation plus the passive transport was considered a reasonable estimate of active transport.

As the period of storage was prolonged, so the ability of the red cell to metabolize glucose deteriorated on incubation. This pointed to a progressive defect in intracorpuscular metabolism, which adenosine could repair more effectively than glucose alone (Table XI). The glucose utilization of the bottom cell fraction was invariably less than samples from the top fraction; allied to this was the finding that the top fraction of cells accumulated more 2:3 DPG than those from the bottom part during incubation. 
Active transport of cations proceeded at a greater rate in the top fraction cells from each time level of storage. Rates of active transport decreased as the cells regained their normal potassium content and extruded sodium; hence the rate of accumulation of red cell potassium and extrusion of sodium decreased with longer times of incubation. Sodium extrusion was always greater than the potassium influx, with restoration of the original cell volume. Active transport rates on incubation were lower for erythrocytes cold-stored longer than 10 days.

\section{DISCUSSION}

Centrifugation or sedimentation of red cells provides a density gradient whereby discrete populations of erythrocytes with different mean ages can be obtained from blood samples. The fractions are not cytochemical or physiological homogeneous populations (28), but they possess a relative concentration of young cells in the upper layers and old cells in the bottom levels. A further method of fractionating red cells into separate age populations is by osmotic lysis $(4,35-37)$, since young cells have been shown to be less fragile osmotically than old cells. Both methods have been validated by $\mathrm{Fe}^{59}$ tagging of newly formed cells of a limited age span (37). While the osmotic fragility method is reported to be more effective in providing fractions with greater enzyme differences for mean cell ages (5), separation by this technique is only suited to experiments not requiring intact cells. The method is therefore inapplicable to studies on metabolic processes in intact red cells.

The mature red cell loses metabolic properties possessed by reticulocytes, viz., ability to incorporate glycine (38) and protoporphyrin (39) into heme; respiration due to mitochondria (4) and the enzymes of the tricarboxylic acid cycle (40); and the presence of ribosenucleic acid with the synthesis of stromal proteins $(41,42)$. Hence the mature erythrocyte would appear to lack the capability of oxidative processes and synthesis of enzymes after the reticulocyte stage.

The metabolic energy of erythrocytes is derived solely from the utilization of sugar, whether glucose, fructose, mannose or ribose from adenosine and other purine ribosides. Glucose utilization by normal red cells from the bottom strata of centrifuged samples was some $4.3 \mu$ Moles per $\mathrm{Gm}$. hemoglobin per hour (corresponding to 1.4 mMoles per L. red cells per hour); reticulocytes could degrade eight times more glucose. Since no alteration occurs in the availability of glucose as substrate, the source of deterioration must be sought in the process of erythrocytic glucose metabolism.

TABLE XI

Potassium accumulation and sodium extrusion of refrigerated, fractioned red cell suspensions incubated at $37^{\circ} \mathrm{C}$. for six hours

\begin{tabular}{|c|c|c|c|c|c|c|c|c|}
\hline & \multirow[b]{3}{*}{ Sample* } & \multirow{3}{*}{$\begin{array}{c}\text { Glucose } \\
\text { utilization }\end{array}$} & \multicolumn{6}{|c|}{ Cation transport $†$} \\
\hline & & & \multicolumn{3}{|c|}{ Potassium gain } & \multicolumn{3}{|c|}{ Sodium loss } \\
\hline & & & Gross & Passive & Active & Gross & Passive & Active \\
\hline \multirow{3}{*}{ A } & \multirow{3}{*}{$\begin{array}{l}\text { Top } \\
\text { Bottom }\end{array}$} & \multirow{3}{*}{$\begin{array}{c}\text { pMoles } / \mathrm{Gm} . \mathrm{Hb} / \mathrm{hr} \text {. } \\
10.8 \\
5.1\end{array}$} & \multicolumn{3}{|c|}{$\mu E q . / G m . H b / h r}$. & \multicolumn{3}{|c|}{$\mu E q . / G m . H b / h r$} \\
\hline & & & 6.1 & 6.5 & 12.6 & $7.6^{-5}$ & 8.3 & 15.9 \\
\hline & & & 2.9 & 6.1 & 9.0 & 5.2 & 6.4 & 11.6 \\
\hline \multirow{2}{*}{ B } & Top & 10.1 & 9.6 & 5.9 & 15.5 & 12.2 & 6.6 & 18.8 \\
\hline & Bottom & 5.3 & 4.0 & 4.9 & 13.3 & 8.7 & 6.1 & 14.8 \\
\hline \multirow[t]{2}{*}{ C } & Top & 9.3 & 9.9 & 4.6 & 14.5 & 11.8 & 5.9 & 17.7 \\
\hline & Bottom & 4.0 & 4.4 & 4.9 & 9.3 & 5.2 & 5.8 & 11.0 \\
\hline \multirow[t]{2}{*}{$\mathrm{D}$} & Top & 8.6 & 7.0 & 3.3 & 10.3 & 9.6 & 5.3 & 14.9 \\
\hline & Bottom & 3.4 & 5.1 & 2.5 & 7.6 & 3.8 & 5.2 & 9.0 \\
\hline \multirow[t]{2}{*}{ Df } & Top & 11.3 & 12.5 & 4.0 & 16.5 & 15.8 & 6.0 & 21.8 \\
\hline & Bottom & 5.5 & 8.4 & 3.5 & 11.9 & 12.5 & 4.4 & 16.9 \\
\hline
\end{tabular}

* A, B, C and D represent samples stored for three, five, seven and 10 days, respectively, and having cation compositions of similar order to those given in Table $\mathrm{X}$. Incubated in medium containing: $\mathrm{Na}, 150 \mathrm{mEq}$. per L.; $\mathrm{K}$, 5 mEq. per L. ; and glucose, $2 \mathrm{mg}$. per $\mathrm{ml}$. in buffered phosphate at $\mathrm{pH} 7.4$.

Transport rates may be converted to $\mu \mathrm{Eq}$. per $\mathrm{ml}$. red cells per hour by using an approximate factor of 0.29 and $0.33 \mathrm{Gm}$. hemoglobin $(\mathrm{Hb})$ per $\mathrm{ml}$. cells for top and bottom fractions, respectively.

$\ddagger \mathrm{D}$ contained in addition, adenosine, $1 \mathrm{mg}$. per $\mathrm{ml}$. 
The conversion of glucose to lactate was near the theoretical equivalent in bottom fraction cells, indicating that the degradation of glucose in the aged cell followed the Embden-Meyerhof route of anaerobic glycolysis. The lesser degree of conversion to lactate for top fraction cells may be attributed to two processes: a) Glucose metabolism is partly deviated via the oxidative pentose phosphate path (43) before re-entering the anaerobic glycolytic sequence (Figure 1). By this route, 3 Moles glucose will be degraded to 5 instead of 6 Moles pyruvate formed via the complete Embden-Meyerhof path. Using glucose$1-\mathrm{C}^{14}$ and glucose-6-C $\mathrm{C}^{14}$, the proportion of glucose that is catabolized directly to lactate- $\mathrm{C}^{14}$ and the fraction that is first shunted via the oxidative pentose phosphate route $\left(\mathrm{C}^{14} \mathrm{O}_{2}\right)$ before re-entering the glycolytic path can be ascertained. Murphy (44) calculated that 10 to 20 per cent of glucose metabolized by human red cells followed the oxidative pathway. Since the glucose-6-phosphate dehydrogenase and 6-phosphogluconic dehydrogenase activity of the most resistant (youngest) to the least resistant (oldest) cells to osmotic lysis ranged from 230 to 20 per cent and 165 to 80 per cent of the whole cell population, respectively (5), and methylene-blue treated top layer cells produced one-third more $\mathrm{O}_{2}$ than bottom fraction cells (45), the reticulocytes and young mature cells from the top layer have a more active metabolism through the shunt than aged cells.

b) Pyruvate is partly deviated via the Krebs tricarboxylic acid cycle with liberation of $\mathrm{CO}_{2}$. This mechanism is confined to the reticulocytes since only these circulating red cells contain enzymes of the cycle (3) and mitochondrial-like structures (4). In particular, the respiration of the reticulocytes is some 30 to 50 times that of the mature red cell, in which it is negligible $(1,42)$.

The different rates of glycolysis in fractional levels of the red cell column, together with glycolytic rates during the maturation of reticulocytes (Table IV), are suggestive evidence of the progressive biochemical maturity of circulating red cells from reticulocytes through young mature to the aged erythrocyte.

The concentration of the two high energy phosphate esters, viz., 2:3 DPG and ATP, in the red cell decreased in the older age fractions of red cells. This is in agreement with the work of Hofmann and Rapoport (46) who found that rabbit reticulocytes had two to three times the ATP content of the average circulating erythrocyte. The human red cell contains a considerable store of 2:3 DPG with a high energy content $(\Delta \mathrm{F}, 16,000$ calories). Through conversion to pyruvate, 2:3 DPG is available to generate the formation of ATP required to prime the hexokinase reaction in the initial phosphorylation of glucose. Without a high level of ATP present for this reaction, the subsequent steps leading to the net synthesis of ATP in the overall glycolytic process cannot proceed. The inherently greater metabolic activity of top fraction cells was evidenced by the greater disappearance of these phosphate esters during incubation without glucose. Subsequent addition of glucose and inorganic phosphate or adenosine (or inosine) led to a more rapid resynthesis of phosphate esters and restoration of glycolytic activity in top fraction cells.

Control of the amounts of glucose degraded must depend ultimately on the levels of enzyme activity in the reactions concerned. Since no alteration in lactic apodehydrogenase activity was found, confirming the results of Marks, Johnson and Hirschberg (5) and Rubinstein, Ottolenghi and Denstedt (40), and the amounts of red cell pyruvate were small $(0.5 \mu$ Mole per $\mathrm{Gm}$. hemoglobin), no defect in the conversion of pyruvate to lactate was found. While the concentration of phosphohexose isomerase and aldolase decreased from the top to the bottom strata of red cells, consideration must be given to the possibility that the concentrations of these enzymes were in such excess that they were not rate-limiting. Marks, Johnson and Hirschberg (5) and Löhr and co-workers (47) reported decreases of these and other red cell enzymes with age while this work was in progress. For overall glycolysis, cells from the bottom strata of centrifuged samples produced some 8 to $9 \mu$ Moles lactate per $\mathrm{Gm}$. hemoglobin per hour (i.e., $3 \mathrm{mMoles}$ per L. red cells per hour). In the enzyme assays, the substrates were added in excess, and calculation of the amount of triose equivalents transformed under these circumstances may be made. Lactic apodehydrogenase activity was computed in terms 
of pyruvate formed by converting the alteration in optical density (O.D.) of reduced diphosphopyridine nucleotide (DPNH), using 6.22 for the molar extinction coefficient. For the normal values given in Table VIII, some 1,450 to 1.750 $\mu$ Moles DPNH per $\mathrm{Gm}$. hemoglobin per hour was converted, i.e., 1,450 to $1,750 \mu$ Moles lactate formed per $\mathrm{Gm}$. hemoglobin per hour. For phosphohexose isomerase activity (unit $=$ conversion to $25 \mu \mathrm{g}$. fructose-6-phosphate in 30 minutes), $7,100,6,440$ and $10,800 \mu$ Moles triose equivalents per $\mathrm{Gm}$. hemoglobin per hour could be transformed for original, bottom and top fraction cells. In the case of aldolase activity, triose equivalents formed were 560, 440, 580 and $930 \mu$ Moles triose per $\mathrm{Gm}$. hemoglobin per hour for original, bottom, middle and top fractions, respectively. Recalculation of the results given by Sibley and Lehninger (25) for rat red cell aldolase activity yields a value of $240 \mu$ Moles triose formed per $\mathrm{Gm}$. hemoglobin per hour for their conditions. For other enzymes concerned in the Embden-Meyerhof path, Solvonuk and Collier (48) reported pyruvic phosphoferase activity for human red cells to be $130 \mu$ Moles pyruvate liberated per $\mathrm{ml}$. cells per 10 minutes, or approximately 2,400 $\mu$ Moles pyruvate produced per Gm. hemoglobin per hour.

The limitation to overall glycolysis must thus arise from rate-limiting enzyme activity in the sequence of glycolysis. Of the enzymes tested, only aldolase activity was low (1 per cent of muscle aldolase activity and about 10 per cent of the activity present in most tissues) and reduction of aldolase activity in old cells may reach a critical level to limit overall glycolysis. Aldolase activity would qualify as one of the rate-limiting steps since phosphohexose isomerase was present in amounts considerably larger than necessitated by its requirement in glycolysis, while the pentose phosphate path is largely confined to reticulocytes. Calculation of values from (5) lead to estimates of 300 and $600 \mu$ Moles triose formed per $\mathrm{Gm}$. hemoglobin per hour for normal and reticulocytosis specimens by this route.

However, the possibility that low hexokinase activity may be present in red cells is being currently investigated for various age fractions of cells and cases with reticulocytosis. Calculated from Crane and Sols' report (49), the red cell hexokinase activity would indicate the formation of $24 \mu$ Moles triose per $\mathrm{Gm}$. hemoglobin per hour. Thus the preliminary step in phosphorylation may be the rate-limiting step for overall glycolysis. The requirement of ATP to prime the initial stage of glycolysis may also play a part in the limitation of glycolysis. High concentrations of ATP are required in the hexokinase reaction and these were found to be diminished in the bottom (old) fraction of centrifuged cells.

The supply of a metabolizable sugar is essential to the energy requirement of active cation transport $(3,50-52)$. Metabolic inhibitors acting at various stages of the pathway of glucose catabolism inhibit active cation transport in varying degree (50). The top fraction (young) human red cells maintained a steady state with higher cell potassium and lower sodium than bottom fraction cells; this may relate to the greater energy supply of the reticulocytes and young mature erythrocytes in the former component.

During refrigeration the greater glycolysis and cation transport of top fraction cells overrode the higher diffusion gradients of potassium or sodium for these cells, and thus the decrease of red cell potassium of top fraction cells was less than for lower strata cells. Incubation of refrigerated cells led to a more rapid rate of glycolysis and more active accumulation of potassium and extrusion of sodium for top fraction cells. While the turnover of potassium and sodium in the red cell is best studied with isotopic tracers, these were not available at the time of the experiments. The data presented were for gross movements under conditions of red cell cation content not met with in vivo and, as such, gave only limited information.

The energy of glycolysis, stored as ATP, is coupled to reactions that maintain active cation transport and the integrity of membrane structure necessary for cell survival. Anaerobic glycolysis yields 2 Moles ATP, with a free energy value in tissues of 22,000 to 24,000 calories, for every Mole glucose metabolized (53). With complete conversion of glucose at the rate of 4.3 $\mu$ Moles per $\mathrm{Gm}$. hemoglobin per hour to lactate in bottom (old) fraction cells, some 0.095 calories per $\mathrm{Gm}$. hemoglobin per hour (29 calories per L. red cells per hour) were available. Since reticulo- 
cyte glycolysis was some eight times greater and a proportion followed the oxidative pentose phosphate and tricarboxylic acid routes, the actual energy yield for reticulocytes was considerably greater. The decrease in glycolytic activity with aging of the red cell may lead to a critical level at which the integrity of membrane function can no longer be maintained. Since a red cell lacking active transport would result in a cell with potassium and sodium ratios approaching $[\mathrm{Cl}]_{\mathrm{Pl}} /$ $[\mathrm{Cl}]_{\mathrm{RBC}}=1.44$ (54), i.e., $[\mathrm{K}]_{\mathrm{RBC}} /[\mathrm{K}]_{\mathrm{Pl}}$ and $[\mathrm{Na}]_{\mathrm{RBC}} /[\mathrm{Na}]_{\mathrm{Pl}}$ of this order with swelling of the cell, deterioration of active cation transport fluxes would lead to alterations in membrane permeability. Decrease of phosphate esters produced an increase in cell inorganic phosphate and diffusion of the inorganic phosphate extracellularly; the decrease in organic cell phosphate would decrease the internal colloid osmotic pressure and decrease the cell volume. Decrease in glycelytic activity may thus diminish the ability of the red cell to stabilize its volume against variations in membrane permeability.

The level of glycolytic activity may play an important role in the oxygen carrying ability of hemoglobin. In hemolysates, hemoglobin is rapidly auto-oxidized to ferric nature, but in the intact cell the reduced pyridine nucleotides (DPNH and TPNH) act as cofactors to the flavoprotein methemoglobin reductase to maintain hemoglobin in the reduced state (3). With decreased glycolysis in aged cells, the generation of reduced di- and triphosphopyridine nucleotides may diminish to subthreshold levels for the cyclic reduction of methemoglobin $\left(\mathrm{Fe}^{+++}\right.$, nonoxygen carrier $)$ to hemoglobin $\left(\mathrm{Fe}^{++}\right.$, oxygen carrier).

Allison and Burn (11) have suggested that decrement in red cell catalase or cholinesterase activity might lead to red cell disintegration; they calculated that the enzyme activity of reticulocytes was some three times that of the average cell population and that the red cell at the termination of its life span has less than 10 per cent of its enzyme activity as a reticulocyte. However, catalase is known to be present in red cells in high concentration and a change in activity of one magnitude is unlikely to be a limiting factor in protecting hemoglobin from oxidation. Further, calculations of the cholinesterase and glyoxa- lase activities of red cells demonstrated that the values reported in aged cells were not rate-limiting, while the suggested role of cholinesterase hydrolysis of acetylcholine providing energy for active cation transport has not been confirmed $(55,56)$.

The disappearance of normal cells from circulation is a linear process (57) and indicative of an intrinsic process of cell breakdown (1). During aging of the red cell, there is a diminution in cell volume, associated with decreases in water, electrolyte and dry solid (except hemoglobin) content (28). Prankerd (7) has reported a lower lipid content of bottom (old) cells compared with the top layer. The alteration in cation and water content may be a reflection of changes thus produced in the passive diffusion and active transport capacity of the lipoprotein membrane. While changes in the lipoprotein surface structure may be due to the buffeting received by red cells in circulation, aged red cells are reported to incorporate less saturated and unsaturated fatty acids from labeled acetate or glucose (58). The ultimate effect could be to render the red cells more susceptible to chemical dissolution of the red cell membrane.

\section{SUM MARY}

Erythrocytes have been separated by centrifugation into cell populations of relatively younger and older age fractions. The rate of glycolysis was less in the moiety of relatively older cells, accompanied by a lower high-energy phosphate ester content and enzyme activity (phosphohexose isomerase and aldolase). Lactic apodehydrogenase activity showed no alteration with cell aging. The aldolase concentration was a ratelimiting factor for overall glycolysis. However, hexokinase activity appeared to be the initial limitation in red cell glycolysis and may have resulted in aged cells from their decreased adenosine triphosphate content.

Cation steady states were at lower levels of active transport in old cells. Incubation without glucose produced greater deterioration of phosphate ester content for the younger cells. Refrigeration of cell fractions produced greater loss of potassium and gain of cell sodium for old cells due to lesser glycolysis; reincubation led to more 
rapid recovery to normal cation contents for young cells.

Alterations in red cell glycolysis with age led to decreased available energy, producing some deterioration of active cation transport and membrane function. It is postulated that decreased glycolytic activity in the aged cell may lower the resistance of cells to destructive processes.

\section{ACKNOWLEDGMENTS}

I am grateful to Professor E. H. Cluver, Director of the South African Institute for Medical Research, for his continued interest in and support of this investigation. I wish to thank colleagues of the Johannesburg Group of Hospitals for specimens, and Dr. O. Bodansky, SloanKettering Institute for Cancer Research, New York, for his advice on the phosphohexose isomerase method. The preliminary part of this work was performed in the Department of Physiology, University of the Witwatersrand, Johannesburg, and I am indebted to Professor J. Gillman for the provision of facilities.

\section{REFERENCES}

1. Ponder, E. Hemolysis and Related Phenomena. New York, Grune and Stratton, 1948.

2. Wintrobe, M. M. Clinical Hematology, 4th ed. Philadelphia, Lea and Febiger, 1956.

3. Prankerd, T. A. J. The metabolism of the human erythrocyte: A review. Brit. J. Haemat. 1955, 1, 131.

4. Chalfin, D. Differences between young and mature rabbit erythrocytes. J. cell. comp. Physiol. 1956, 47, 215.

5. Marks, P. A., Johnson, A. B., and Hirschberg, E. Effect of age on the enzyme activity in erythrocytes. Proc. nat. Acad. Sci. (Wash.) 1958, 44, 529.

6. Borun, E. R., Figueroa, W. G., and Perry, S. M. The distribution of $\mathrm{Fe}^{\mathrm{s}}$ tagged human erythrocytes in centrifuged specimens as a function of cell age. J. clin. Invest. 1957, 36, 676.

7. Prankerd, T. A. J. The ageing of red cells. J. Physiol. (Lond.) 1958, 143, 325.

8. Keitel, H. G., Berman, H., Jones, H., and MacLachlan, E. The chemical composition of normal human red blood cells, including variability among centrifuged cells. Blood 1955, 10, 370 .

9. Kruszynski, J. A cytochemical study of reticulocytes by microincineration. Acta Anat. (Basel) 1955, 24, 164.

10. Sabine, J. C. The cholinesterase of erythrocytes in anemias. Blood 1951, 6, 151.

11. Allison, A. C., and Burn, G. P. Enzyme activity as a function of age in the human erythrocyte. Brit. J. Haemat. 1955, 1, 291.

12. Marks, P. A. Red cell glucose-6-phosphate and 6phosphogluconic dehydrogenases and nucleoside phosphorylase. Science 1958, 127, 1338.
13. Bernstein, R. E. The correction of mean cell volume and mean cell haemoglobin concentration. J. clin. Path. 1955, 8, 225.

14. Dacie, J. V. Practical Haematology, 2nd ed. London, J. and A. Churchill, 1956.

15. King, E. J., and Wootton, I. D. P. Micro-analysis in Medical Biochemistry, 3rd ed. London, J. and A. Churchill, 1956.

16. Bernstein, R. E. Flame analysis of sodium and potassium in small volumes of serum, heparinized plasma and cerebrospinal fluid. Amer. J. clin. Path. 1953, 23, 933.

17. Bernstein, R. E. Sources of interferences in the flame spectrophotometric estimation of calcium and magnesium in biological fluids and tissues in Proceedings, Sixth International Spectroscopic Colloquium, Amsterdam, 1956. London, Pergamon Press, 1957, p. 50.

18. Froesch, E. R., and Renold, A. E. Specific enzymatic determination of glucose in blood and urine using glucose oxidase. Diabetes 1956, 5, 1.

19. Barker, S. B., and Summerson, W. H. The colorimetric determination of lactic acid in biological material. J. Biol. Chem. 1941, 138, 535.

20. Friedemann, T. E., and Haugen, G. E. Pyruvic acid. II. The determination of keto acids in blood and urine. J. biol. Chem. 1943, 147, 415.

21. Bartlett, G. R., Savage, E., Hughes, L., and Marlow, A. A. Carbohydrate intermediates and related cofactors in the human erythrocyte. J. appl. Physiol. 1953, 6, 51.

22. Prankerd, T. A. J., and Altman, K. I. A study of the metabolism of phosphorus in mammalian red cells. Biochem. J. 1954, 58, 622.

23. Gourley, D. R. H. The role of adenosine triphosphate in the transport of phosphate in the human erythrocyte. Arch. Biochem. 1952, 40, 1.

24. Bodansky, O. Serum phosphohexose isomerase in cancer. I. Method of determination and establishment of range of normal values. Cancer 1954, 7, 1191.

25. Sibley, J. A., and Lehninger, A. L. Determination of aldolase in animal tissues. J. biol. Chem. 1949, $177,859$.

26. Beck, W. S. Determination of triose phosphates and proposed modifications in the aldolase method of Sibley and Lehninger. J. biol. Chem. 1955, 212, 847.

27. Blanchaer, M. C., and Baldwin, S. L. Pyruvate accumulation in preserved blood. J. appl. Physiol. 1953, 6, 8.

28. Bernstein, R. E. Physicochemical changes during ageing of mammalian erythrocytes. Submitted for publication.

29. Bartlett, G. R., and Marlow, A. A. Comparative effects of the different formed elements on normal human blood glycolysis. J. appl. Physiol. 1953. 6, 335. 
30. Bernstein, R. E. Rates of glycolysis in human red cells in relation to energy requirements for cation transport. Nature 1953, 172, 911.

31. Seip, M. Reticulocyte studies. Acta med. scand. 1953, Suppl. 282, 146.

32. Whittam, R. Potassium movements and ATP in human red cells. J. Physiol. (Lond.) 1958, 140, 479.

33. Raker, J. W., Taylor, I. M., Weller, J. M., and Hastings, A. B. Rate of potassium exchange of the human erythrocyte. J. gen. Physiol. 1950, 33, 691.

34. Post, R. L., and Jolly, P. C. The linkage of sodium, potassium and ammonium active transport across the human erythrocyte membrane. Biochim. biophys. Acta 1957, 25, 118.

35. Simon, E. R., and Topper, Y. J. Fractionation of human erythrocytes on the basis of their age. Nature 1957, 180, 1211.

36. Jaffé, E. R., Vanderhoff, G. A., Lowy, B. A., and London, I. M. The relationship of the age of rabbit erythrocytes to the effects of inosine on their osmotic resistance. J. clin. Invest. 1958, 37, 1293.

37. Marks, P. A., and Johnson, A. B. Relationship between the age of human erythrocytes and their osmotic resistance: A basis for separating young and old erythrocytes. J. clin. Invest. 1958, 37, 1542.

38. London, I. M., Shemin, D., and Rittenberg, D. Synthesis of heme in vitro by the immature non-nucleated mammalian erythrocyte. J. biol. Chem. 1950, 183, 749.

39. Watson, C. J., and Clarke, W. O. The occurrence of protoporphyrin in the reticulocytes. Proc. Soc. exp. Biol. (N. Y.) 1937, 36, 65.

40. Rubinstein, D., Ottolenghi, P., and Denstedt, O. F. The metabolism of the erythrocyte. XIII. Enzyme activity in the reticulocyte. Canad. J. Biochem. 1956, 34, 222.

41. Muir, H. M., Neuberger, A., and Perrone, J. C. Further isotopic studies on haemoglobin formation in the rat and rabbit. Biochem. J. 1952, 52, 87.

42. Bartlett, G. R., and Marlow, A. A. Erythrocyte carbohydrate metabolism. I. The flow of $\mathrm{C}^{14}$ glucose carbon into lactic acid, carbon dioxide, cell polymers, and carbohydrate intermediate pool. J. Lab. clin. Med. 1953, 42, 178.

43. Racker, E. Alternate pathways of glucose and fructose metabolism. Advanc. Enzymol. 1954, 15, 141.
44. Murphy, J. R. Demonstration of aerobic oxidative glucose metabolism in the erythrocyte (abstract). J. Lab. clin. Med. 1957, 50, 936.

45. Marks, P. A., Johnson, A. B., Hirschberg, E., and Banks, J. Studies on the mechanism of aging of human red blood cells. Ann. N. Y. Acad. Sci. 1958, 75, 95.

46. Hofmann, E. C. G., and Rapoport, S. Das Verhalten von Triphospho-pyridinnucleotid, Flavinadenin-dinucleotid, Coenzym A, und Thiaminpyrophosphat in Hämolysaten von Kaninchen-Reticulocyten und -Erythrocyten. Hoppe-Seylers Z. physiol. Chem. 1956, 304, 157.

47. Löhr, G. W., Waller, H. D., Karges, O., Schlegel, B., and Müller, A. A. Zur Biochemie der Alterung menschlicher Erythrocyten. Klin. Wschr. 1958, 36, 1008.

48. Solvonuk, P. F., and Collier, H. B. The pyruvic phosphoferase of erythrocytes. I. Properties of the enzyme and its activity in erythrocytes of various species. Canad. J. Biochem. 1955, 33, 38.

49. Crane, R. K., and Sols, A. The association of hexokinase with particulate fractions of brain and other tissue homogenates. J. biol. Chem. 1953, 203, 273.

50. Maizels, M. Factors in the active transport of cations. J. Physiol. (Lond.) 1951, 112, 59.

51. Harris, E. J. Transport and Accumulation in Biological Systems. London, Butterworth, 1956.

52. Glynn, I. M. Sodium and potassium movements in human red cells. J. Physiol. (Lond.) 1956, 134, 278.

53. Burton, K. Energy of adenosine triphosphate. Nature 1958, 181, 1594.

54. Bernstein, R. E. Potassium and sodium balance in mammalian red cells. Science 1954, 120, 459.

55. Taylor, I. M., Weller, J. M., and Hastings, A. B. Effect of cholinesterase and choline acetylase inhibitors on the potassium concentration gradient and potassium exchange of human erythrocytes. Amer. J. Physiol. 1952, 168, 658 .

56. Goodman, J. R., Marrone, L. H., and Squire, M. C. Effect of in vivo inhibition of cholinesterase on potassium diffusion from the human red cell. Amer. J. Physiol. 1955, 180, 118.

57. Eadie, G. S., and Brown, I. W., Jr. Red blood cell survival studies. Blood 1953, 8, 1110.

58. James, A. T., Lovelock, J. E., and Webb, J. P. W. The biosynthesis of fatty acids by the human red blood cell in Essential Fatty Acids, H. M. Sinclair, Ed. London, Butterworth, 1958, p. 72. 